\title{
Optimization of Biogas Production in a Batch Laboratory Digester Using Total Solids, Substrate Retention Time, and Mesophilic Temperature
}

\author{
Barasa H. Masinde ${ }^{1^{*}}$, Daudi M. Nyaanga ${ }^{2}$, Musa R. Njue ${ }^{2}$ and Joseph W. Matofari ${ }^{3}$ \\ ${ }^{1}$ Mechanical and Industrial Engineering Department, Masinde Muliro University of Science and Technology, P.O. \\ Box 190 - 50100, Kakamega, KENYA. \\ ${ }^{2}$ Agricultural Engineering Department, Egerton University, P.O. Box 536 - 20115, Egerton, KENYA. \\ ${ }^{3}$ Dairy, Food Science and Technology, Egerton University, P.O. Box 536 - 20115, Egerton, KENYA. \\ Email: he.masb62@gmail.com
}

\begin{abstract}
Optimization was done by investigating the interaction effects of total solids, mesophilic temperature, and substrate retention time on biogas production in a batch biodigester. The volume of the biodigester was $0.15 \mathrm{~m}^{3}$. Central composite design of Response Surface Methodology was used to design the experiment. Total solid levels were varied from $6.31 \%$ to $9.68 \%$, temperature was from $26.59^{\circ} \mathrm{C}$ to $43.41^{\circ} \mathrm{C}$, and substrate retention time was from 9.95 to 20.04 days. Analysis of results was done using Design Expert software statistical package (version 10.0.0.3). It gave a coefficient of determination of 0.9665 which indicated a high correlation between the variables. All the variables had a significant effect. The highest biogas production rate of 75.41 litres/day (or $0.50 \mathrm{~m}^{3}$ of biogas per $\mathrm{m}^{3}$ of digester volume per day, $\mathrm{m}^{3} / \mathrm{m}^{3} \mathrm{~d}$ ) was achieved at a level of $8 \%$ total solids, a temperature of $43.41^{\circ} \mathrm{C}$, and a substrate retention time of 15 days.
\end{abstract}

Keywords: optimization, biogas production, total solids, mesophilic temperature, substrate retention time.

\section{Introduction}

Optimization is the act of achieving the best possible result under given circumstances. In design, construction and maintenance, engineers have to make decisions. The aim of such decisions is either to minimize the effort or to maximize benefit. The effort or benefit can be expressed as a function of certain design variables. Hence optimization is the process of finding conditions that give the minimum or the maximum value of a function [1]. Efforts to maximize biogas production are currently being done by using various feedstocks. Reungsang et al [2] used Response surface methodology (RSM) with a central composite design (CCD) to optimize the key factors affecting methane production from the acidic effluent coming from the sugarcane juice hydrogen fermentation process. The parameters studied were substrate concentration, ratio of $\mathrm{NaHCO}_{3}$ to substrate concentration, and initial $\mathrm{pH}$. The maximum methane yield of $367 \mathrm{~mL} \mathrm{CH} / \mathrm{g}$-volatile solid (VS) added was obtained at the optimum conditions of $13,823 \mathrm{mg}-\mathrm{COD} / \mathrm{L}$, an $\mathrm{NaHCO}_{3}$ to substrate concentration ratio of 3.09, and an initial pH of 7.07. Methane yield was enhanced 4.4-fold in comparison to raw effluent. Sathish and Vivekanadan [3] studied the optimal conditions for biogas generation from anaerobic digestion of rice straw in a $1 \mathrm{~m}^{3}$ floating drum anaerobic digester using RSM. The parameters were temperature, $\mathrm{pH}$, substrate concentration, and agitation time. The highest level of biogas of $0.72 \mathrm{~m}^{3}$ was produced at an optimum temperature of $50^{\circ} \mathrm{C}, \mathrm{pH} 7.5$, substrate concentration of $110.70 \mathrm{~kg}$, and an agitation time of 5 seconds, respectively. Saleh et al [4] investigated the effects of temperature, palm oil mill effluent (POME) volume, inoculum volume, and co-substrate addition such as oil palm empty fruit bunch (EFB) and palm kernel on the anaerobic digestion process for biogas and methane production. RSM by BoxBehnken design verified that the specific biogas production rate and methane yield were mainly affected by the operating temperature and co-substrate addition. The optimal conditions for the maximum specific biogas production rate $\left(0.0574 \mathrm{~m}^{3} / \mathrm{kg}\right.$ chemical oxygen demand per day) and methane yield $(25.6 \%)$ were predicted by multiple response optimization and verified experimentally at $47.8^{\circ} \mathrm{C}$ 
operating temperature, $50.4 \mathrm{~mL}$ POME volume, and $5.7 \mathrm{~g}$ EFB addition. Other similar works have been reported by Pannucharoenwong[5] among others.

Response surface methodology (RSM) is one of the most effective approaches for designing experiments, for building models, and for determining optimal conditions on responses which are influenced by several independent variables [6-9]. Apart from defining the influences of independent variables on the responses, RSM also determines the effect of interaction between parameters to obtain the best performance on a system [10,11]. Experiments designed by using RSM have fewer runs, and also give similar results which are comparable to a full-factorial design, and enables an effective evaluation of interaction between individual factors to provide the best combination for optimal performance $[12,13]$. RSM is a collection of statistical and mathematical techniques used for developing, improving, and optimizing processes [14]. The most extensive applications of RSM are in situations where several input variables potentially influence some performance measure or quality characteristic of a process; most applications of RSM are sequential in nature, and are performed within some region of the independent variable space called the operability region [15]. RSM is robust; it makes the process consistent on target, and is relatively insensitive to factors that are difficult to control $[16,17]$.

Two types of RSM are used in design of experiments: Box-Wilson, and Box-Behnken [18]. The BoxWilson, which is also called central composite design (CCD), has three different design points: edge points are in two-level designs $( \pm 1)$, star points at $\pm \alpha$ that take care of quadratic effects, and centre points (0) [13]. CCD does testing at five levels. The edge points are at the design limits, star points are at some distance from the centre depending on the number of factors in the design; the star points extend the range outside the low and high settings for all factors, while the centre points complete the design [19]. CCD provides high quality predictions over the entire design space, is suitable for fitting a quadratic surface, and usually works well for process optimization [20]. Box-Behnken design is an independent quadratic design because it does not contain an embedded factorial or fractional factorial design [21]. In this design, the treatment combinations at the midpoints of edges of the process space and at the centre, require three levels of each factor: $-1,0$, and +1 , and has fewer treatment combinations than CCD [19].

A biodigester is any manufactured device or system in which a biologically active environment or a chemical process is carried out which involves microorganisms or biochemically active substances derived from such organisms is supported [22]. There are many designs of biogas plants but the most common ones in Kenya include the lagoon, floating drum, fixed dome and flexible structure bio-digester models $[23,24]$. A fixed dome is a biodigester which consists of a reactor with a fixed, non-movable gas holder, which sits on the reactor. Regarding the flow pattern of anaerobic digesters, two basic types can be distinguished: batch and continuous. In continuous flow reactors the processes involved in anaerobic digestion proceed spatially as well as temporarily in parallel steps whereas batch reactors exhibit temporarily staggered sequences [25]. The operation of batch-type digesters consists of loading the digester with organic materials and allowing it to digest; once the digestion is complete, the effluent is removed and the process is repeated [25].

A parameter is any of the factors that limit the way in which something can be done. In this study, the parameters that have been considered are total solids, temperature, and substrate retention time; and their effect on biogas production rate in a fixed dome biodigester under laboratory conditions. Biodigesters operate at different environmental and management conditions. Other parameters that affect the efficient production of biogas include lack of feedstock, appropriate design of digesters, development of inoculums, $\mathrm{pH}$, loading rate, hydraulic retention time (HRT), Carbon: Nitrogen (C:N) ratio, and volatile fatty acids [26]. Defects in digester construction and microbiological failure are, also, major areas of concern and are crucial for the optimization of biogas production technologies and their economic viability [27].

Total solids are defined as a measure of dry matter left after the moisture has been removed from a moist sample. Substrate concentration can be determined in terms of volatile solids or total solids. Volatile solids content is determined by igniting the feedstock at $550^{\circ} \mathrm{C}$ in an incinerator and then weighing the remaining contents [28]. Total solids is the measurement of dry matter as a percentage, and is determined by drying the sample at $103-105^{\circ} \mathrm{C}$ in succession until no further change in weight is observed [28].

Anaerobic fermentation is, in principle, possible between a temperature of $3^{\circ} \mathrm{C}$ and approximately $70^{\circ} \mathrm{C}[25]$. There are three main temperature regimes for anaerobic digestion (AD): psychrophilic $(<$ 
$\left.25^{\circ} \mathrm{C}\right)$, mesophilic $\left(30-40^{\circ} \mathrm{C}\right)$ and thermophilic $\left(50-70^{\circ} \mathrm{C}\right)[29]$. The best temperatures are $10^{\circ} \mathrm{C}, 37^{\circ} \mathrm{C}$ and $52^{\circ} \mathrm{C}$ for psychrophilic, mesophilic, and thermophilic bacteria, respectively [30]. In $\mathrm{AD}$, the formation and consumption of products at different temperatures can occur at different rates, causing transient accumulation of potentially inhibitory substances [31]. Consequently, temperature is a critical factor affecting anaerobic digestion because it influences both system heating requirements and methane production [32].

Substrate retention time refers to the mean length of time that the material fed into the batch digester takes before it is emptied [33]. Shorter retention times are known to be associated with acidification especially fatty acids, and can cause inhibitory effects [34]. Nonetheless, shorter substrate retention times allow for increased process efficiency and decreased capital costs, although longer substrate retention times are necessary for the digestion of lignocellulosic wastes [35]. Generally, mesophilic digestion can be accomplished within 15 - 30 days [36].

\section{Materials and Methods}

\subsection{Design of Experiment}

Central composite design was used to get the matrix of experiments with three factors, each being tested at five different levels. The response was biogas production $(Y)$. The factors were: substrate retention time $\left(x_{1}\right)$, total solids $\left(x_{2}\right)$, and temperature $\left(x_{3}\right)$. Design Expert software (version 10.0.0.3, Stat-Ease, Inc., Minneapolis, United States) statistical package was used to generate Table 1 and Table 2 for the experiment. The levels of every factor were as indicated in Table 1. In the design space, the highest level was coded as +1 , the centre point was 0 , and the lowest level was coded as -1 . The outer design space points corresponding to $\alpha$ were $\pm 1.68179 . \alpha=2^{k / 4}$, where $\mathrm{k}$ is the number of factors [8, 37]. In this case, $k=3$. There was a total of 20 runs of experiments; comprising of 6 centre points and 14 axial points. If a full factorial experiment were done, there would have been $5^{3}$ (or 125) runs of experiments.

Table 1. Factors and their coded and actual values

\begin{tabular}{cccccccc}
\hline \multirow{2}{*}{ Factor } & \multirow{2}{*}{ Symbol } & \multirow{2}{*}{ Unit } & \multicolumn{5}{c}{ Coded and Actual Values } \\
\cline { 4 - 8 } & & & -1.68 & -1.00 & 0.00 & +1.00 & +1.68 \\
\hline \multirow{2}{*}{ SRT } & $x_{1}$ & days & 9.95 & 12.00 & 15.00 & 18.00 & 20.04 \\
TS & $x_{2}$ & $\%$ & 6.31 & 7.00 & 8.00 & 9.00 & 9.68 \\
Temp & $x_{3}$ & ${ }^{\circ} \mathrm{C}$ & 26.59 & 30.00 & 35.00 & 40.00 & 43.41 \\
\hline
\end{tabular}

Actual values $\left(x_{i}\right)$ were found from equation $(1)[2,36,38]$ as:

$$
x=\frac{x_{i}-x_{0}}{\Delta x}
$$

where:

$$
\begin{aligned}
& i=1,2, \text { and } 3 \\
& x_{\mathrm{i}}=\text { the input variable } \\
& x_{0}=\text { the value of } x_{\mathrm{i}} \text { at the centre point } \\
& \Delta x=\text { the step change between input variables } \\
& x=\text { the coded value. }
\end{aligned}
$$

\subsection{Statistical Analysis and Modeling}

A second order mathematical model was used to fit the quadratic equation [39-42] as given below.

$$
Y=\beta_{0}+\sum_{i} \beta_{i} x_{i}+\sum_{i j} \beta_{i j} x_{i} x_{j}+\sum_{i i} \beta_{i i} x_{i}^{2}
$$

The interpretation of equation (2) is as follows: 


$$
Y=\beta_{0}+\beta_{1} x_{1}+\beta_{2} x_{2}+\beta_{3} x_{3}+\beta_{12} x_{1} x_{2}+\beta_{13} x_{1} x_{3}+\beta_{23} x_{2} x_{3}+\beta_{11} x_{1}^{2}+\beta_{22} x_{2}^{2}+\beta_{33} x_{3}^{2}
$$

where:

$Y$ is the measured response

$x_{1}, x_{2}$, and $x_{3}$ are coded input variables

$\beta_{0}$ is the intercept term

$\beta_{1}, \beta_{2}$, and $\beta_{3}$ are coefficients showing the linear effects

$\beta_{12}, \beta_{13}$, and $\beta_{23}$ are cross-product coefficients showing the interaction effects

$\beta_{11}, \beta_{22}$, and $\beta_{33}$ are the quadratic coefficients

\subsection{Verification of Optimized Results}

In this study, optimization was done with the predictive model for the response as a function of substrate retention time, total solids, and temperature. The model was based on results from CCD on biogas production. Setting numerical optimization criteria was by Design Expert software (version 10.0.0.3). This software uses an optimization method developed by Derringer and Suich [43], and is described by Montgomery, et al. [14]. This criteria was also used by Avicenna, et al. [44]. The objective function was to maximize biogas production $(\mathrm{Y})$; subject to the variables (A: substrate retention time, B: total solids, and C: temperature) and their respective constraints as shown below:

Maximize

$$
\begin{aligned}
& Y=-901.41+15.21 A+183.25 B+7.74 C-0.56 A B+0.04 A C+0.06 B C \\
& -0.41 A^{2}-11.47 B^{2}-0.11 C^{2}
\end{aligned}
$$

Subject to: $12 \leq \mathrm{A} \leq 18 ; 7 \leq \mathrm{B} \leq 9 ; 30 \leq \mathrm{C} \leq 40$

Table 2. Criteria.

\begin{tabular}{cccc}
\hline Name & Goal & Lower limit & Upper limit \\
\hline A: SRT (days) & In range & 12.00 & 18.00 \\
B: TS $(\%)$ & In range & 7.00 & 9.00 \\
C: Temp $\left({ }^{\circ} \mathrm{C}\right)$ & In range & 30.00 & 40.00 \\
Y: Biogas production (litres/day) & Maximize & 33.01 & 75.41 \\
\hline
\end{tabular}

This procedure generated Table 3 .

Table 3. Influent preparation

\begin{tabular}{cccc}
\hline TS (\%) & Cow dung: water dilution & Cow dung $(\mathrm{kg})$ & Water $(\mathrm{kg})$ \\
\hline 7.642 & $1: 1.441$ & 49.160 & 70.840 \\
7.697 & $1: 1.424$ & 49.505 & 70.495 \\
7.724 & $1: 1.416$ & 49.669 & 70.331 \\
\hline
\end{tabular}

Gas collection was by water displacement method. Biogas analysis was done using a Gas Chromatograph. Experiments were done on the first three optimized solutions. The results were compared. 


\section{Results}

Table 4. Experiment matrix, actual and predicted results

\begin{tabular}{c|ccc|cccc}
\hline \multirow{3}{*}{ Run } & \multicolumn{3}{|c|}{ Factors } & \multicolumn{4}{c}{ Biogas production } \\
\cline { 2 - 7 } & $\begin{array}{c}\text { A:SRT } \\
(\text { days })\end{array}$ & $\begin{array}{c}\text { B:TS } \\
(\%)\end{array}$ & $\begin{array}{c}\text { C:Temp } \\
\left({ }^{\circ} \mathrm{C}\right)\end{array}$ & $\begin{array}{c}\text { Actual } \\
(\mathrm{l} / \mathrm{d})\end{array}$ & $\begin{array}{c}\text { Predicted } \\
(\mathrm{l} / \mathrm{d})\end{array}$ & $\begin{array}{c}\text { Actual } \\
\left(\mathrm{m}^{3} / \mathrm{m}^{3} \mathrm{~d}\right)\end{array}$ & $\begin{array}{c}\text { Predicted } \\
\left(\mathrm{m}^{3} / \mathrm{m}^{3} \mathrm{~d}\right)\end{array}$ \\
\hline 1 & 15.00 & 8.00 & 35.00 & 72.11 & 73.16 & 0.48 & 0.48 \\
2 & 15.00 & 8.00 & 35.00 & 72.90 & 73.16 & 0.48 & 0.48 \\
3 & 15.00 & 6.32 & 35.00 & 45.73 & 51.82 & 0.30 & 0.34 \\
4 & 15.00 & 8.00 & 35.00 & 71.56 & 73.16 & 0.47 & 0.48 \\
5 & 18.00 & 7.00 & 40.00 & 66.91 & 68.89 & 0.44 & 0.45 \\
6 & 12.00 & 7.00 & 40.00 & 67.48 & 65.35 & 0.44 & 0.43 \\
7 & 15.00 & 8.00 & 26.59 & 52.71 & 55.96 & 0.35 & 0.37 \\
8 & 18.00 & 9.00 & 30.00 & 36.40 & 39.99 & 0.24 & 0.26 \\
9 & 15.00 & 8.00 & 35.00 & 71.80 & 73.16 & 0.47 & 0.48 \\
10 & 15.00 & 8.00 & 35.00 & 71.96 & 73.16 & 0.47 & 0.48 \\
11 & 15.00 & 9.68 & 35.00 & 33.01 & 29.74 & 0.22 & 0.19 \\
12 & 15.00 & 8.00 & 35.00 & 72.30 & 73.16 & 0.48 & 0.48 \\
13 & 12.00 & 9.00 & 30.00 & 45.88 & 45.57 & 0.30 & 0.30 \\
14 & 20.04 & 8.00 & 35.00 & 61.52 & 61.88 & 0.41 & 0.41 \\
15 & 12.00 & 7.00 & 30.00 & 58.00 & 55.95 & 0.38 & 0.37 \\
16 & 12.00 & 9.00 & 40.00 & 52.65 & 56.17 & 0.35 & 0.37 \\
17 & 9.95 & 8.00 & 35.00 & 61.25 & 63.56 & 0.40 & 0.42 \\
18 & 18.00 & 7.00 & 30.00 & 59.14 & 57.09 & 0.39 & 0.38 \\
19 & 18.00 & 9.00 & 40.00 & 49.17 & 52.99 & 0.32 & 0.35 \\
20 & 15.00 & 8.00 & 43.41 & 75.41 & 74.79 & 0.50 & 0.49 \\
\hline & & & & & & & \\
\hline
\end{tabular}

Table 5. Analysis of variance

\begin{tabular}{crrrrr}
\hline Source & Sum of Squares & df & Mean Square & F Value & p-value Prob $>$ F \\
\hline Model & 3037.53 & 9 & 337.50 & 32.09 & $<0.0001$ \\
A-SRT & 10.43 & 1 & 10.43 & 0.99 & 0.3428 \\
B-TS & 577.69 & 1 & 577.69 & 54.93 & $<0.0001$ \\
C-Temp & 411.52 & 1 & 411.52 & 39.13 & $<0.0001$ \\
AB & 22.88 & 1 & 22.88 & 2.18 & 0.1710 \\
AC & 2.30 & 1 & 2.30 & 0.22 & 0.6500 \\
BC & 0.66 & 1 & 0.66 & 0.062 & 0.8079 \\
A $^{2}$ & 194.38 & 1 & 194.38 & 18.48 & 0.0016 \\
B $^{2}$ & 1891.36 & 1 & 1891.36 & 179.83 & $<0.0001$ \\
C $^{2}$ & 107.16 & 1 & 107.16 & 10.19 & 0.0096 \\
Residual & 105.17 & 10 & 10.52 & & \\
Cor Total & 3142.71 & 19 & & & \\
\hline
\end{tabular}

Other Statistics

$\mathrm{R}^{2}=0.9665$; Adjusted $\mathrm{R}^{2}=0.9364$; Predicted $\mathrm{R}^{2}=0.7442$; C.V. $\%=5.41$; Adequate

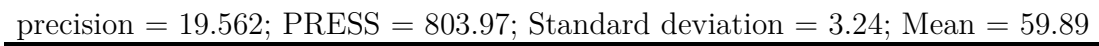




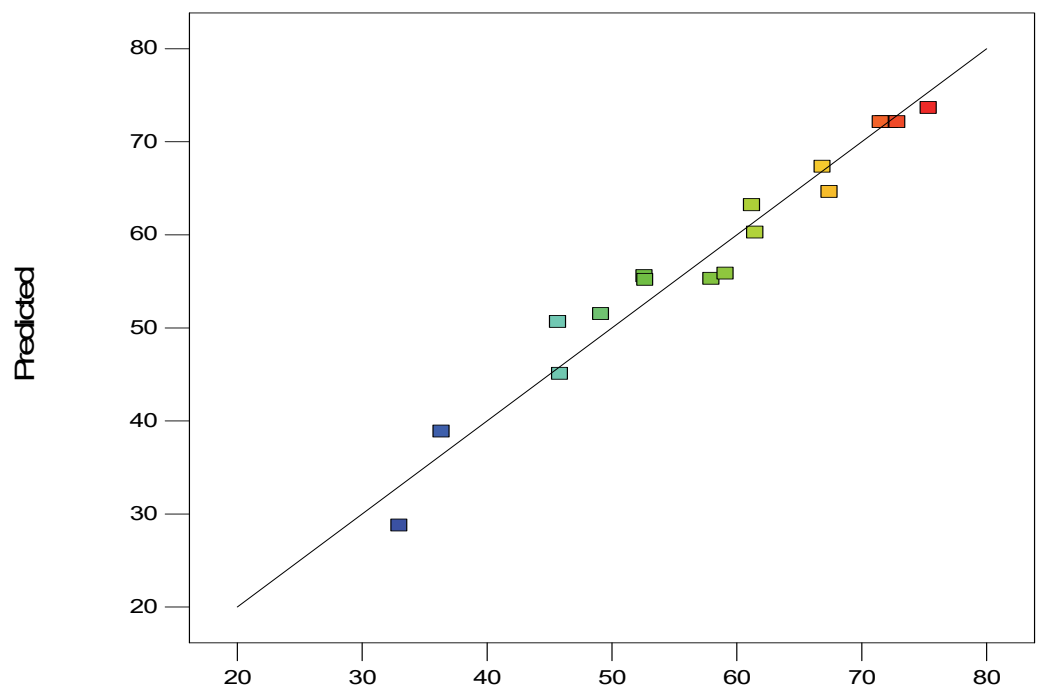

Actual

Figure 1. Predicted vs Actual results

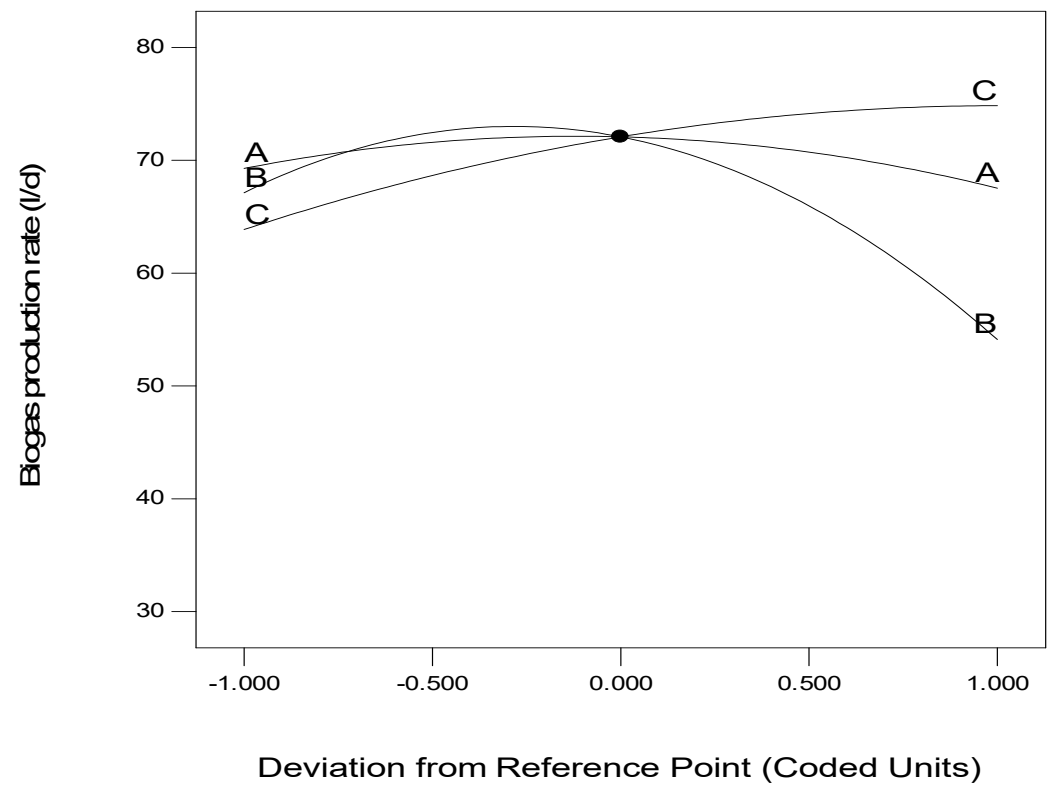

Figure 2. Perturbation

Table 6. Optimized results and experimental results

\begin{tabular}{c|ccc|cc}
\hline \multirow{2}{*}{ Solution } & \multicolumn{3}{|c|}{ Factors } & \multicolumn{2}{c}{ Biogas production (l/d) } \\
\cline { 2 - 6 } & SRT (days) & TS $(\%)$ & Temp $\left({ }^{\circ} \mathrm{C}\right)$ & Optimized & Experiment \\
\hline 1 & 15.339 & 7.642 & 39.643 & 75.578 & 69.855 \\
2 & 15.179 & 7.697 & 39.202 & 75.612 & 70.929 \\
3 & 15.385 & 7.724 & 38.979 & 75.530 & 68.247 \\
\hline
\end{tabular}




\section{Discussions}

\subsection{Prediction Model}

Experimental results as well as the predicted values for biogas production rate are given in Table 4. A combination of factors which yielded the highest biogas production of 75.41 litres per day (or $0.502 \mathrm{~m}^{3}$ of biogas per $\mathrm{m}^{3}$ of digester volume per day, $\mathrm{m}^{3} / \mathrm{m}^{3} \mathrm{~d}$ ) was a substrate retention time of 15 days, total solids of $8 \%$, and a temperature of $43.4^{\circ} \mathrm{C}$.

A regression analysis was done based on the experimental results using the Design Expert 10.0.0.3 statistical package, and it yielded a relationship given by equation (4) with its respective boundary limits. Equation (4) was used to predict the values corresponding to the actual ones, and most of them are very close. These values are in agreement with $0.4 \mathrm{~m}^{3} / \mathrm{m}^{3} \mathrm{~d}$ reported by Nyaanga [45], and Moog, et al. [46].

\subsection{Analysis of Variance (ANOVA)}

The analysis of variance is necessary in order to determine the significance and adequacy of the model [42]. The statistical significance of the second-order polynomial equation was checked by an F-test (ANOVA). Table 5 shows the statistics. The ANOVA was used to evaluate the significance of the quadratic polynomial model [47]. For each term in the model, a large F-value and a small P-value would imply a more significant effect on the respective response variable [48].

A model F-value of 32.09 was found. There was a chance of less than $0.01 \%$ that a value this much could be caused by noise. Hence the model was chosen for the experiment. Model values whose 'prob>F' are less than 0.05 (i.e. $\mathrm{p}<0.05)$ are significant. In this case, the linear effects of total solids $(\mathrm{B})$ and temperature $(C)$ were significant. The quadratic effects of substrate retention time $\left(\mathrm{A}^{2}\right)$, total solids $\left(\mathrm{B}^{2}\right)$, and temperature $\left(\mathrm{C}^{2}\right)$ were significant. The interaction effects of $\mathrm{AB}, \mathrm{AC}$ and $\mathrm{BC}$ were insignificant. All the significant factors had an individual effect on biogas production rate.

A coefficient of determination $\left(\mathrm{R}^{2}\right)$ is used to measure the variability in the actual response values that can be described by the corresponding independent factors [40]. $\mathrm{R}^{2}$ was 0.9665 ; it implied that a sample variation of $96.65 \%$ of the total variation could be explained by the model, and only $3.35 \%$ could not be explained by the model for this work. For a good statistical model, the $\mathrm{R}^{2}$ should be in the range of $0.75-1.0$ which indicates a good fit of the model [49].

The adjusted $\mathrm{R}^{2}$ of 0.9364 was also very high. It indicated the higher significance of the model. The predicted $R^{2}$ value of 0.7442 showed reasonable agreement with the adjusted $R^{2}$ value of 0.9364 . The threshold is that the difference between the adjusted $\mathrm{R}^{2}$ and the predicted $\mathrm{R}^{2}$ should be less than 0.2 [50]. The difference here is 0.1922 . This indicated a good agreement between the observed and the predicted values as demonstrated in table 5 .

The percentage of coefficient of variation (CV \%) is a measure of residual variation of the data relative to the size of the mean; the higher the value of $\mathrm{CV}$, the lower is the reliability of experiment [51]. A lower CV of $5.41 \%$ indicated a greater reliability of the experiment. As a general rule, a model can be considered reasonably reproducible if the CV is not greater than $10 \%$ [52]. This model is reproducible.

Adequate precision is a measure of signal to noise ratio; a ratio greater than 4 is desirable [53]. In this case, the ratio was 19.562; which indicated an adequate signal. This model can be used to navigate the design space. The Predicted Residual Sum of Squares (PRESS) is a measure of how well the model fits each point in the design; the smaller the PRESS statistics, the better would be the model fitting the data points [52]. Here the value of PRESS found was 803.97. This value is small; it shows that the model fits well on each point in the design.

\subsection{Diagnostics}

Figure 1 shows that the predicted results lie within the normal probability curve. The actual results also exhibit the same behavior. Outliers also exist, implying the errors inherent in the experiment due to the losses of biogas and the accuracy of the equipment used to monitor the anaerobic process. However, a 
high $\mathrm{R}^{2}$ value that was found emphasizes a high degree of similarity that was observed between the predicted and the experimental values. It can be concluded that the model has satisfied the assumptions of the analysis of variance and also reflected the accuracy and applicability of RSM to optimize the process factors for the efficient generation of biogas [40].

\subsection{Perturbation}

Perturbation is a deviation of a system, moving object, or process from its regular or normal state or path, caused by outside influence. Perturbation plot provides silhouette views of the response surface. For response surface designs, the perturbation plot shows how the response changes as each factor moves from the chosen reference point, with all other factors held constant at the reference value [54]. Design Expert sets the reference point default at the middle of the design space (the coded zero level of each factor).

Figure 2 represents a comparison of the effect of process parameters at the midpoint (coded 0 ) in the design space. When B (TS) and C (Temperature) are held at their respective midpoints, it shows that A (SRT) gives a steadily higher biogas production rate from day 12 up to its midpoint value (day 15), and then the rate starts decreasing. Similarly for B, the rate increases from $6.31 \%$ TS, then starts dropping before the midpoint ( $8 \% \mathrm{TS}$ ) is reached. Thereafter the rate decreases steadily. For C, the rate increases uniformly from $25^{\circ} \mathrm{C}$ to the midpoint $\left(35^{\circ} \mathrm{C}\right)$, then the trend continues up to $40^{\circ} \mathrm{C}$.

\subsection{Verification of Optimized Results}

The results are given in table 6 . It can be observed that the optimized biogas production for solutions 1 , 2 and 3 are higher than experimental ones by $8.19 \%, 6.60 \%$ and $10.67 \%$, respectively. For the results to be valid, the difference between the actual value and the predicted value should be less than $20 \%$ [50]. The differences are within the range hence the optimization is admissible.

\section{Conclusions}

During optimization, a biogas production rate of $75.41 \mathrm{l} / \mathrm{d}\left(\right.$ or $\left.0.50 \mathrm{~m}^{3} / \mathrm{m}^{3} \mathrm{~d}\right)$ was achieved at a substrate retention time of 15 days, $8 \%$ total solids, and a temperature of $43.41^{\circ} \mathrm{C}$. Optimized results are in agreement with the experimental results.

Acknowledgment. The project was funded by the National Council for Science, Technology, and Innovation (Nacosti). We are also grateful to Egerton University for hosting the project.

\section{References}

1. A. Astolfi and L. Praly. "Global complete observability and output-to-state stability imply the existence of a globally convergent observer". Mathematics of Control, Signals and Systems, vol. 18, no. 1, pp. 32-65, 2006.

2. A. Reungsang, P. Sakchai and S. Sureewan. "Optimization of key factors affecting Methane production from acidic effluent coming from the sugarcane juice Hydrogen fermentation process.". Energies, vol. 5, pp. 4746-4757, 2012.

3. S. Sathish and S. Vivekanandan. "Parametric optimization for floating drum anaerobic bio-digester using Response Surface Methodology and Artificial Neural Network". Alexandria Engineering Journal, vol. 55, no. 4, pp. 3297-3307, 2016.

4. A. Saleh, E. Kamarudin, A. Yaacob, A. Yussof and M. Abdullah. "Optimization of biomethane production by anaerobic digestion of palm oil mill effluent using response surface methodology". Asia-Pacific Journal of Chemical Engineering, no. 7, pp. 353-360, 2012.

5. N. Pannucharoenwong. "Optimization of Bio-Methane Production from Mesophilic Anaerobic Co-digestion of Pig Manure and Vegetable Residue". International Journal of Applied Engineering Research, vol. 13, no. 4, pp. 1988-1995, 2018. 
6. A. Ahmad, S. Low, S. Shukor and A. Ismail. "Optimization of membrane performance by thermal-mechanical stretching process using response surface methodology (RSM)". Sep PurifTechnol, vol. 66, no. 1, pp. 177-186, 2009.

7. M. A. Bezerra, R. E. Santelli, E. P. Oliveira, L. S. Villar and L. A. Escaleira. "Response surface methodology (RSM) as a tool for optimization in analytical chemistry". Talanta, vol. 76, no. 5, pp. 965-977, 2008.

8. N. Aslan. "Application of response surface methodology and central composite rotatable design for modeling the influence of some operating variables of a multi-gravity separator for coal cleaning". Fuel, vol. 86, no. 5-6, pp. 769-776, 2007.

9. J. Kang, S. Kim and B. Moon. "Optimization by response surface methodology of Lutein recovery from paprika leaves using accelerated solvent extraction". Food chemistry, vol. 205, pp. 140-145, 2016.

10. T. Belwal, P. Dhyani, I. D. Bhatt, R. S. Rawal and V. Pande. "Optimization extraction conditions for improving phenolic content and antioxidant activity in Berberis asiatica fruits using response surface methodology (RSM)". Food chemistry, vol. 207, pp. 115-124, 2016.

11. Z. Zaroual, H. Chaair, A. Essadki, K. El Ass and M. Azzi. "Optimizing the removal of trivalent chromium by electrocoagulation using experimental design". Chemical Engineering Journal, vol. 148, no. 2-3, pp. 488-495, 2009.

12. G. Khoobbakht, G. Najafi, M. Karimi and A. Akram. "Optimization of operating factors and blended levels of diesel, biodiesel and ethanol fuels to minimize exhaust emissions of diesel engine using response surface methodology". Applied Thermal Engineering, vol. 99, pp. 1006-1017, 2016.

13. J. Jiménez, Y. Guardia-Puebla, O. Romero-Romero, M. Cisneros-Ortiz, G. Guerra, J. Morgan-Sagastume and A. Noyola. "Methanogenic activity optimization using the response surface methodology, during the anaerobic codigestion of agriculture and industrial wastes Microbial community diversity". Biomass Bioenerg, vol. 71, pp. 84-97, 2014.

14. D. C. Montgomery, G. C. Runger and N. F. Hubele, Engineering statistics. John Wiley and Sons, 2009.

15. K. M. Carley and N. Y. Kamneva, A network optimization approach for improving organizational design, Carnigie-Mellon Univ Pittsburg PA, 2004.

16. G. Taguchi, System of Experimental Design: Engineering Methods to Optimize Quality and Minimize Cost. UNIPUB/Kraus International, 1987.

17. G. Taguchi, Introduction to Quality Engineering. Asian Productivity Organization, 1986.

18. M. Jain, V. Garg and K. Kadrivelu. "Investigation of $\mathrm{Cr}(\mathrm{VI})$ adsorption onto Chemically treated Helianthus annus: optimization using Response Surface Methodology". Bioresource Technology, vol. 102, pp. 600-605, 2011.

19. K. Leiviskä, Introduction to Experiment Design. Control Engineering Laboratory, 2013.

20. M. Kousha, S. Tavakoli, E. Daneshvar, A. Vazirzadeh and A. Bhatnagar. "Central Composite design optimization of Acid Blue 25 dye biosorption using shrimp shell biomass". Journal of Molecular Liquids vol. 207, pp. 266-273, 2015.

21. Z. Kong, M. Li, J. Chen, Y. Bao, B. Fan, F. Francis and X. Dai. "Processing factors of triadimefon and triadimenol in barley brewing based on response surface methodology". Food Control vol. 64, pp. 81-86, 2016.

22. IUPAC, Compendium of Chemical Terminology. 2nd ed., 2006.

23. D. Nyaanga, Biogas Systems in Kenya Report, Egerton University, Egerton University, 2007.

24. M. Schön, Numerical modelling of anaerobic digestion processes in agricultural biogas plants. BoD-Books on Demand, 2010.

25. B. Eder and H. Schulz, Biogas Praxis [in German]. 3rd ed., 2006.

26. C. Nzila, J. De Wulf, H. Spanjers, H. Kiriamiti and H. Langenhove. "Biowaste energy potential in Kenya". Renewable Energy, vol. 35, no. 12, pp. 2698-2704, 2010.

27. B. Nijaguna, Biogas technology. New Age International, 2006.

28. EPA. "Method 1684: Total, Fixed, and Volatile Solids in Water, Solids, and Biosolids". U.S. Environmental Protection Agency, 2001.

29. J. Meegoda, B. Li, K. Patel and L. Wang. "A review of the processes, parameters, and optimization of anaerobic digestion". International Journal of Environmental Research and Public Health, vol. 15, no. 10, pp. 2224, 2018.

30. I. Patharwat, S. Kumbhar, P. Hingalaje, A. Khurpe, J. Goudgaon and P. Dhamangaonkar. "Analysis of optimum temperature and validity of biogas plant". International Journal of Industrial Electronics and Electrical Engineering, vol. 4, no. 4, pp. 76, 2016.

31. R. Labatut, L. Angenent and N. Scott. "Conventional mesophilic vs. thermophilic anaerobic digestion: a tradeoff between performance stability? ". Water Research, no. 53, pp. 249-258, 2014. 
32. R. Ramaraj and Y. Unpaprom. "Effect of temperature on the performance of biogas production from Duckweed". Chemistry Research Journal, vol. 1, no. 1, pp. 58-66, 2016.

33. M. Kircher, D. M. Witten, P. Jain, B. J. O'Roak, G. M. Cooper and J. Shendure. "A general framework for estimating the relative pathogenicity of human genetic variants". Nature genetics, vol. 46, no. 3, pp. 310, 2014.

34. C.-S. Hwu, B. Donlon and G. Lettinga. "Comparative toxicity of long-chain fatty acid to anaerobic sludges from various origins". Water Science and Technology, vol. 34, no. 5-6, pp. 351-358, 1996.

35. X. Shi, J. Dong, J. Yu, H. Yin, S. Hu, S. Huang and X. Yuan. "Effect of hydraulic retention time on anaerobic digestion of wheat straw in the semi-continuous continuous stirred-tank reactors". BioMed Res. Int, 2017.

36. C. Mao, Y. Feng, X. Wang and G. Ren. "Review on research achievements of biogas from anaerobic digestion". Renew. Sustain. Energy Rev, vol. 45, pp. 540-555, 2015.

37. S. Ahmad. "Techniques for inducing accelerated corrosion of steel in concrete". Arabian Journal for Science and Engineering, vol. 34, no. 2, pp. 95, 2009.

38. S. Christakos, P. Dhawan, A. Verstuyf, L. Verlinden and G. Carmeliet. "Vitamin D: metabolism, molecular mechanism of action, and pleiotropic effects". Physiological reviews, vol. 96, no. 1, pp. 365-408, 2015.

39. J. Feng, J. Zhang, J. Zhang, Y. He, R. Zhang, C. Chen and G. Liu. "Enhanced methane production of vinegar residue by response surface methodology (RSM)". Amb Express, vol. 7, no. 1, pp. 89, 2017.

40. D. Mukhopadhyay, J. P. Sarkar and S. Dutta. "Optimization of process factors for the efficient generation of biogas from raw vegetable wastes under the direct influence of plastic materials using Taguchi methodology". Desalination and Water Treatment, vol. 51, no. 13, pp. 2781-2790, 2013.

41. B. S. Beevi, G. Madhu and D. K. Sahoo. "Performance and kinetic study of semi-dry thermophilic anaerobic digestion of organic fraction of municipal solid waste". Waste management, vol. 36, pp. 93-97, 2015.

42. P. Thanwised, W. Wirojanagud and A. Reungsang. "Effect of hydraulic retention time on hydrogen production and chemical oxygen demand removal from tapioca wastewater using anaerobic mixed cultures in anaerobic baffled reactor (ABR)". International Journal of Hydrogen Energy, vol. 37, no. 20, pp. 15503-15510, 2012.

43. G. Derringer and R. Suich. "Simultaneous optimization of several response variables". Journal of quality technology, vol. 12, no. 4, pp. 214-219, 1980.

44. Avicenna, M. Mela, S. Ihsan and R. Setyobudi. "Process Improvement of Biogas Production from Anaerobic Codigestion of Cow Dung and Corn Husk". Procedia Chemistry, no. 14, pp. 91-100, 2015.

45. D. Nyaanga, Performance of Tropical Biogas, Egerton University International Conference, Egerton University, Kenya, 2011.

46. H. Moog, A. Avilla, E. Agpaoa, F. Valenzuela and F. Concepcion. "Promotion and utilization of polyethylene bio-digester in small-holder farming systems in the Philippines". Livestock Research for Rural Development, vol. 9, no. 2, pp., 1997.

47. J. Nanduri, G. Yuan, G. K. Kumar, G. L. Semenza and N. R. Prabhakar. "Transcriptional responses to intermittent hypoxia". Respiratory physiology $\&$ neurobiology, vol. 164, no. 1-2, pp. 277-281, 2008.

48. L. Quanhong and F. Caili. "Application of response surface methodology for extraction optimization of germinant pumpkin seeds protein". Food chemistry, vol. 92, no. 4, pp. 701-706, 2005.

49. K. Niladevi, R. K. Sukumaran, N. Jacob, G. Anisha and P. Prema. "Optimization of laccase production from a novel strain-Streptomyces psammoticus using response surface methodology". Microbiological research, vol. 164, no. 1, pp. 105-113, 2009.

50. B. Subha, Y. C. Song and J. H. Woo. "Optimization of biostimulant for bioremediation of contaminated coastal sediment by response surface methodology (RSM) and evaluation of microbial diversity by pyrosequencing". Marine pollution bulletin, vol. 98, no. 1-2, pp. 235-246, 2015.

51. Z. Šumić, A. Vakula, A. Tepić, J. Čakarević, J. Vitas and B. Pavlić. "Modeling and optimization of red currants vacuum drying process by response surface methodology (RSM)". Food chemistry, vol. 203, pp. 465-475, 2016.

52. J. Rasouli, B. Ciric, J. Imitola, P. Gonnella, D. Hwang, K. Mahajan, E. R. Mari, F. Safavi, T. P. Leist and G.-X. Zhang. "Expression of GM-CSF in T cells is increased in multiple sclerosis and suppressed by IFN- $\beta$ therapy". The Journal of Immunology, vol. 194, no. 11, pp. 5085-5093, 2015.

53. R. Mason, R. Gunst and J. Hess, Statistical design and analysis of experiments, eight applications to engineering and science. 2nd ed., Wiley, 2003.

54. D. Mukhopadhyay, J. P. Sarkar and S. Dutta. "Optimization of process parameters for the economical generation of biogas from raw vegetable wastes under the positive influence of plastic materials using response surface methodology". Journal of Biochemical Technology, vol. 4, no. 1, pp. 549-553, 2013. 